\title{
HYDROCHEMICAL AND GEOLOGICAL CORRELATION TO ESTABLISH THE GROUNDWATER SALINITY OF THE COASTAL AQUIFER OF THE MANGLARALTO RIVER BASIN, ECUADOR
}

\author{
FERNANDO MORANTE ${ }^{1}$, F. JAVIER MONTALVÁN ${ }^{2}$, PAÚL CARRIÓN ${ }^{3}$, GRICELDA HERRERA ${ }^{2}$, \\ JAVIER HEREDIA ${ }^{4}$, F. JAVIER ELORZA ${ }^{5}$, DAYANNA PILCO ${ }^{3} \&$ JOSELYNE SOLÓRZANO $^{3}$ \\ ${ }^{1}$ Facultad de Ciencias Naturales y Matemáticas, ESPOL Polytechnic University, Ecuador \\ ${ }^{2}$ Facultad de Ciencias de la Ingeniería, Universidad Estatal Península de Santa Elena (UPSE), Ecuador \\ ${ }^{3}$ Facultad de Ingeniería en Ciencias de la Tierra FICT, ESPOL Polytechnic University, Ecuador \\ ${ }^{4}$ Instituto Geológico y Minero de España, Spain \\ ${ }^{5}$ ETSI de Minas de Madrid, Universidad Politécnica de Madrid, Spain
}

\begin{abstract}
The Manglaralto aquifer is located at the north of the province of Santa Elena, Ecuador, its importance is based on the source of supply for the sector. The objective of this work is to characterize the waters of this hydrogeological system by means of hydrochemical techniques (Piper and Stiff diagrams) and their correlation with the geology of the area, as well as the determination of marine intrusion. The methodology used is based on the concentrations of the major ions, which have been obtained by the water-rock interaction, where the geological analysis helps to understand the conceptual hydrogeological model. The obtained results indicate that there are two groups of waters: in the part closest to the interior of the basin with facies mainly bicarbonate and calcium-sodium, while nearest the sea shows markedly calcified calcium facies, and the existence of marine intrusion in the well closest to the coastline.
\end{abstract}

Keywords: hydrochemistry, aquifer, marine intrusion, salinity.

\section{INTRODUCTION}

The coastal zones comprise a very important economic axis, due to the port, touristic and gastronomic facilities that are settled in it, and because of this the population in these areas is over one billion inhabitants, which represents approximately $13 \%$ of the world population [1]-[3], because these cities and coastal communities demand considerable water resources, both for domestic supply and for agricultural and industrial production, the water running through the coastal aquifers is important, as is the case of the Pavanje river basin where the coastal aquifer of Karnataka (India) is located, where the majority of the population in this area depends on agriculture [4]. However, these may be affected by the high demand for fresh water, which makes it important that they are managed properly since more than $60 \%$ of the world's population is concentrated in these areas [5], that has led to unplanned exploitation causing serious problems of water quality [6].

Factors such as changes in the discharge of rivers, the regulation of groundwater levels by means of climatic conditions such as rainfall, the use of water without considering the adequate flows in irrigation for agricultural activities, as well as the infiltration in the riverbed, they are important factors that contribute to the contamination of aquifers [7]. The infiltration, product of the precipitations, contributes to the dissolution of evaporitic materials present in the soils, which leads to the increase of the salinity of the aquifers, product of that natural leaching [8].

Coastal watersheds are the ones that present the greatest risk to saline intrusion, because the piezometric levels descend mainly to two factors: the absence of rainfall or the excessive exploitation of the aquifers, which makes the water gradient reduce, so that sometimes the 
flow is reversed in the inland direction, which favours the intrusion of seawater to be present [4]. The coastal aquifer of Mar del Plata in north-eastern Argentina shows an increase in the rate of growth of the population of approximately 10,000 inhabitants in the second half of the 20th century, which has increased the extraction by pumping of the aquifer [9].

The problems of marine intrusion affect the increase of chlorides, which leads to the water quality of the aquifer being affected mainly by the increase of this ion. In the Daweijia area of northern China, the carbonate coastal aquifers are monitored by wells, in which the salinity level is measured basically by the amount of the $\mathrm{Cl}$ ion, in conjunction with the water levels, given that the levels are affected by the increase in density [10]. In Ecuador, the Manglaralto River aquifer, which is the main source of water for the parish of the same name, Valencia [11], indicates that the wells with the best water quality $(\mathrm{CE}<2000 \mathrm{uS} / \mathrm{cm})$ are the most away from the sea, so the measurements of electrical conductivity (EC) show that salt water penetrates the aquifer [12].

Hydrogeochemical investigations allow to identify the water-rock interaction, which provides the chemical footprint due to dissolution processes of materials present in the sector, it can also be used as a tracer of groundwater [13], with what the processes of salinization in coastal aquifers are not exclusive to the intrusion of seawater, but other factors such as the lithological one, that is to say, the presence of evaporite materials that dissolve with the water of the subsoil, this due to the infiltration, as well as the groundwater flow [14]. There are also karst-type aquifers in which the chemistry of their waters are typical of the materials present, such as the Yangtze River in China, which stores its water in the valley of Anshun, and which has highly heterogeneous characteristics, its hydrochemical study is based mainly on the major ions of $\mathrm{Ca}, \mathrm{Mg}, \mathrm{HCO}_{3}, \mathrm{SO}_{4}$, generated from the dissolution of its carbonate rocks [15].

The peninsula of Santa Elena (PSE), located in the center-west of the coast of Ecuador, is the part of the continental territory that excels in the coastal edge. Currently, it has problems both in the distribution and in the supply of water needed by the communities [16]. In the southern part of this province, water supply is mainly provided by the Daule-Santa Elena water transfer, while the northern zone is supplied mainly by groundwater from the aquifers in the sector. The precipitation and the average annual ETP between the period 2000-2015 are respectively 389 and $1250 \mathrm{~mm}$, which shows that there is a water deficit in the basin, this due to the conditions of the semi-arid climate in this area, and the increase of the pumping extractions, being the main (exclusive) source of recharge of the Manglaralto aquifer the precipitations in the basin of the river that takes the same name. The distribution of the liquid extracted from the aquifer is managed by the Regional Drinking Water Board of Manglaralto (JAAPMAN) which has 12 wells drilled [17], supplying the communities of Montañita, Manglaralto, Río Chico, Cadeate, San Antonio and Libertador Bolívar [18], which together reach a population of around 23,586 people, highlighting that it is a tourist and gastronomic area, in which the floating population at beach time can triple the demand for water, which causes an overexploitation of the aquifer [19].

The objective of this work is to characterize the waters that circulate through this hydrogeological system by means of hydrochemical techniques and their relationship with the geology of the area, as well as the analysis of the presence of marine intrusion for making decisions according to correct aquifer management in terms of its quality for human consumption. 


\section{AREA OF STUDY}

\subsection{Geology}

The Manglaralto aquifer is located in the western foothills of the Chongón-Colonche mountain range, where the storage rock that composes the aquifer is alluvial deposits, with powers ranging from a few meters (3-5) to several tens of meters (25-30). These deposits are of Holocene age and rest discordantly on rocks of ages ranging from the Upper Cretaceous to the Lower Miocene. The stratigraphic sequence from wall to ceiling is as follows: Fm. Key with a powerful volcano-sedimentary sequence that crops out in the upper basin, as well as the Fm. Guayaquil that overrides the Fm. Cayo, which emerges in a sequence of a few meters of power and its characteristics are chert-type shales [20]. The stratigraphic sequences that surpass the Fm. Guayaquil, present characteristics of the shallow marine environment with calcareous contributions product of transgressions and marine regressions. These stratigraphic calcareous sequences are: The Superior Member of the Fm. San Eduardo (Member Javita) of the Middle Eocene, formed by a calcareous flysch [20], in which calcarenites of coarse grain are alternated with microbreaks and microconglomerates with predominance of fragments of fossilized algae, with macro contents foraminifera of Eocene genus lepidocycline and discocycline, pelecypod molluscs, spicules of bivalve remains, echinoderm spicules and bryozoan spines. It overlies this member the Fm. Relief (Middle and Upper Eocene), followed by Fm. Dry (Upper Eocene), these two formations are part of the Ancon Group, and also with calcareous characteristics. Followed by this, the Zapotal Member and the Member Dos Bocas (Lower Miocene) belonging to the Fm. Tosagua (Fig. 1). The presence of chlorides in these geological formations is due to the interaction of these rocks with seawater.

\subsubsection{Hydrogeology}

In the Manglaralto river basin, materials of Holocene age, gravels, sands, silts and clays are deposited mainly, in which an aquifer (alluvial terrace) develops, through which flows a single groundwater flow. This flow starts in the upper basin, infiltrates the alluvial terrace in the middle basin and advances to the lower basin, where the alluvial reaches its highest

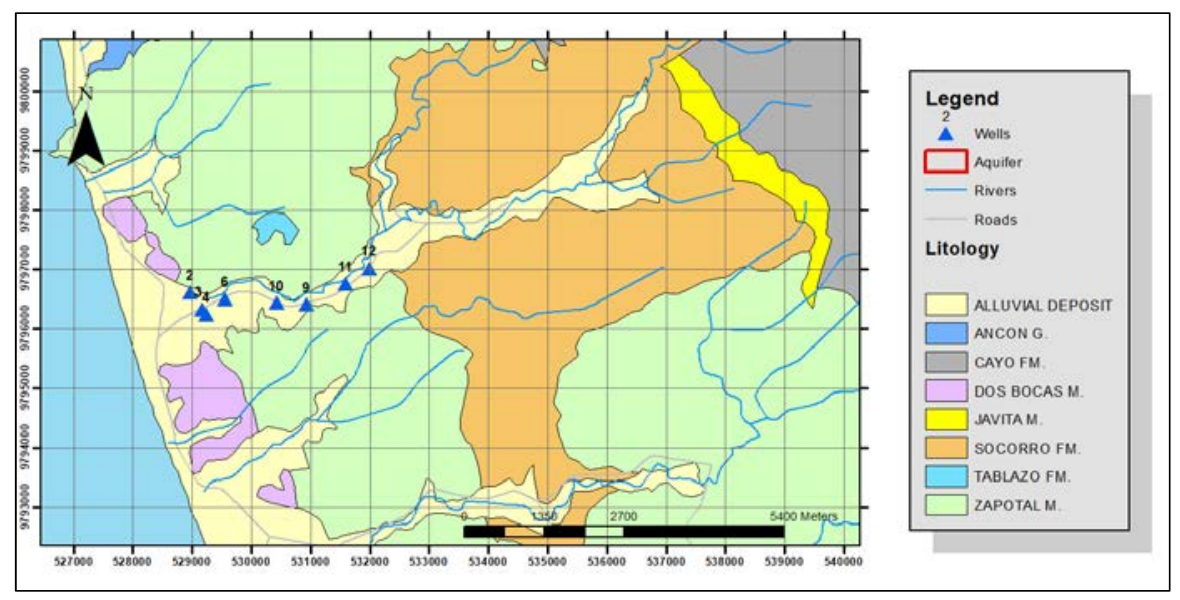

Figure 1: Geological map of the study area, highlighting the alluvial terrace that forms the aquifer of the Manglaralto river basin, scale 1:250.000 [21]. 
power. The hydrogeological characteristics of the aquifer monitored by the Center for Research and Projects Applied to Earth Sciences (CIPAT) of the ESPOL Polytechnic University in 2015 indicate that the porosity is between $0.2-0.3$, the permeability between $1.6-5 \mathrm{~m} / \mathrm{d}$ and the storage coefficient in 0.002 . The power of this aquifer is varied, so the transmissivity is also, this is because in the upper basin the power of the alluvial terrace where the aquifer develops reaches $3 \mathrm{~m}$, increasing in the middle basin to 5-6 m, while in the lower basin it is where it reaches the highest power, which is $30 \mathrm{~m}$, which is where water is extracted to supply the communities.

\section{METHODOLOGY}

\subsection{Hydrochemistry}

A sampling campaign was executed, which was carried out in the month of August 2018 (harvest season), in which eight drilled wells were sampled, which are used for supply. Sampling and analysis were carried out in the certified Gruentec laboratory, which followed the protocols established for water extracted from wells, while in the laboratory the water analyzes were carried out with certified methods. In all the samples, the contents of major ions were analysis, to characterize and establish the type of water to which it belongs. For sampling, the pumping system was off for 12 hours, enough time for the aquifer levels to recover and the sampling to be representative.

The characterization of the waters of the aquifer has been carried out using the Piper diagram and the Stiff diagram, using the INAQUAS 1.9 specialized program of the Instituto Geológico y Minero de España (IGME). To know if the marine intrusion wedge is present inside the aquifer, chlorides analysis was carried out, given that seawater contains a marked trace of the $\mathrm{Cl}$ ion, as well as the $\mathrm{Cl} / \mathrm{Br}$ ratio, which indicates the origin of water with chlorine content.

\subsection{Hydrochemical relationship with the geology of the sector}

The characteristic chemical imprint present in groundwater is acquired by the interaction of the fluid with the rocks or materials during its journey through the basin. In the present work, field campaigns have been carried out to obtain geological data, in which different formations have been identified in the basin and their relationship with the Manglaralto aquifer, due to the dissolution of the rocks due to the passage of the groundwater flow. It should also be considered that the in-situ infiltration of the precipitation on the alluvial terrace leaves a chemical imprint, a process in which the water that runs vertically is in contact with the alluvial deposits. This correlation makes it possible to establish the chemistry of the water, as well as to know its possible origin according to the geological formations present in the area.

\section{RESULTS}

\subsection{Hydrochemistry}

The water samples were taken in August 2018 (Tables 1 and 2), to characterize them by means of the diagram of Piper (Fig. 2) and Stiff (Fig. 3), it results that there are two families of waters in the Manglaralto coastal aquifer. The first of these families has mainly bicarbonate, calcium, and sodium facies, while the second group has markedly calcified calcium facies. 
Table 1: Physical parameters of the groundwater samples of the Manglaralto aquifer taken from the extraction wells of the JAAPMAN.

\begin{tabular}{cccccc}
\hline No. & Well name & $\mathrm{pH}$ & $\mathrm{T}\left({ }^{\circ} \mathrm{C}\right)$ & $\begin{array}{c}\mathrm{TSD} \\
(\mathrm{mg} / \mathrm{l})\end{array}$ & $\begin{array}{c}\text { C.E. } \\
(\mu \mathrm{S} / \mathrm{cm})\end{array}$ \\
\hline 1 & P 12 & 7.5 & 25.2 & 613 & 1731 \\
2 & P 11 & 7.2 & 26 & 572 & 1512 \\
3 & P 09 & 7.5 & 24.6 & 775 & 1729 \\
4 & P 10 & 7.2 & 24.5 & 646 & 1700 \\
5 & P 06 & 7.5 & 26.1 & 696 & 1757 \\
6 & P 03 & 7.2 & 26.9 & 1242 & 3240 \\
7 & P 04 & 7.7 & 26 & 2116 & 5370 \\
8 & P 02 & 7.1 & 26.5 & 2869 & 7080 \\
\hline
\end{tabular}

Table 2: Chemical composition of the groundwater samples of the Manglaralto aquifer taken from the extraction wells of the JAAPMAN.

\begin{tabular}{cccccccccc}
\hline No. & $\begin{array}{c}\text { Well } \\
\text { name }\end{array}$ & $\mathrm{Na}$ & $\mathrm{K}$ & $\mathrm{Ca}$ & $\mathrm{Mg}$ & $\mathrm{Cl}$ & $\mathrm{Br}$ & $\mathrm{SO}_{4}$ & $\mathrm{HCO}_{3}$ \\
\hline 1 & P 12 & 93 & 8.2 & 90 & 20 & 101 & 0.44 & 149 & 330 \\
2 & P 11 & 74 & 7.4 & 87 & 15 & 86 & 0.4 & 121 & 303 \\
3 & P 09 & 133 & 6.5 & 87 & 22 & 111 & 0.5 & 176 & 391 \\
4 & P 10 & 110 & 6.4 & 76 & 16 & 108 & 0.57 & 137 & 323 \\
5 & P 06 & 126 & 8.1 & 96 & 18 & 90 & 0.42 & 178 & 327 \\
6 & P 03 & 187 & 12 & 239 & 46 & 370 & 2.1 & 176 & 309 \\
7 & P 04 & 317 & 14 & 346 & 73 & 723 & 3.8 & 394 & 383 \\
8 & P 02 & 274 & 18 & 588 & 110 & 1224 & 5.1 & 272 & 303 \\
\hline
\end{tabular}

The analyzes indicate that the chlorine content remains constant inside the aquifer, increasing considerably in wells near the sea. It is observed that the section corresponding to wells 6, 9 and 10 are considerably sodium (see the location of wells in Fig. 1).

Also, it emphasizes that when there is more influence of the sea, that is, wells 2, 3 and 4 , these become calcic; this can occur because the calcareous materials of the base of the aquifer, when in contact with very concentrated waters such as seawater, would increase this dissolution process of these materials, thus increasing the calcium ion.

The Stiff diagrams have been located along the Manglaralto river basin, in which we can distinguish spatially the concentration obtained by the groundwater in the water-rock interaction, charging in ions of the different metals and non-metals, distinguishing chlorine remains constant inside the basin, which indicates that there may be a source of chlorine that is in contact with the water of the aquifer, you can also see that this concentration increases considerably in wells near the sea.

\subsection{Ionic relationships}

The $\mathrm{Cl}$ and $\mathrm{Br}$ ions can be affected by different physical processes, such as dilution, evaporation and mixing, which can vary their absolute concentration, but not the $\mathrm{Cl} / \mathrm{Br}$ ratio, so Alcalá and Custodio [22] made a classification of the different waters of the Iberian Peninsula, obtaining a characterization regarding the possible origin of the analyzed waters. 


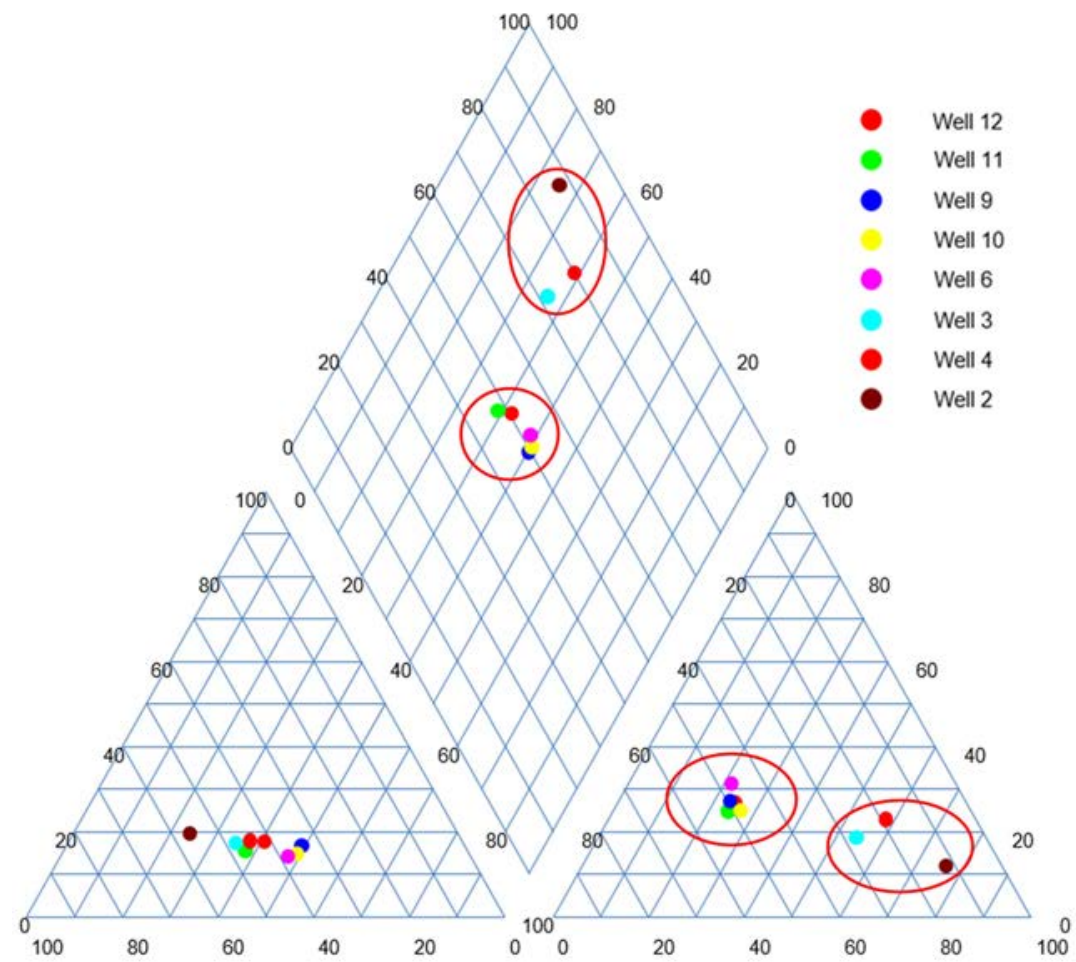

Figure 2: Piper diagram, which indicates the presence of two water families according to their major ion content.

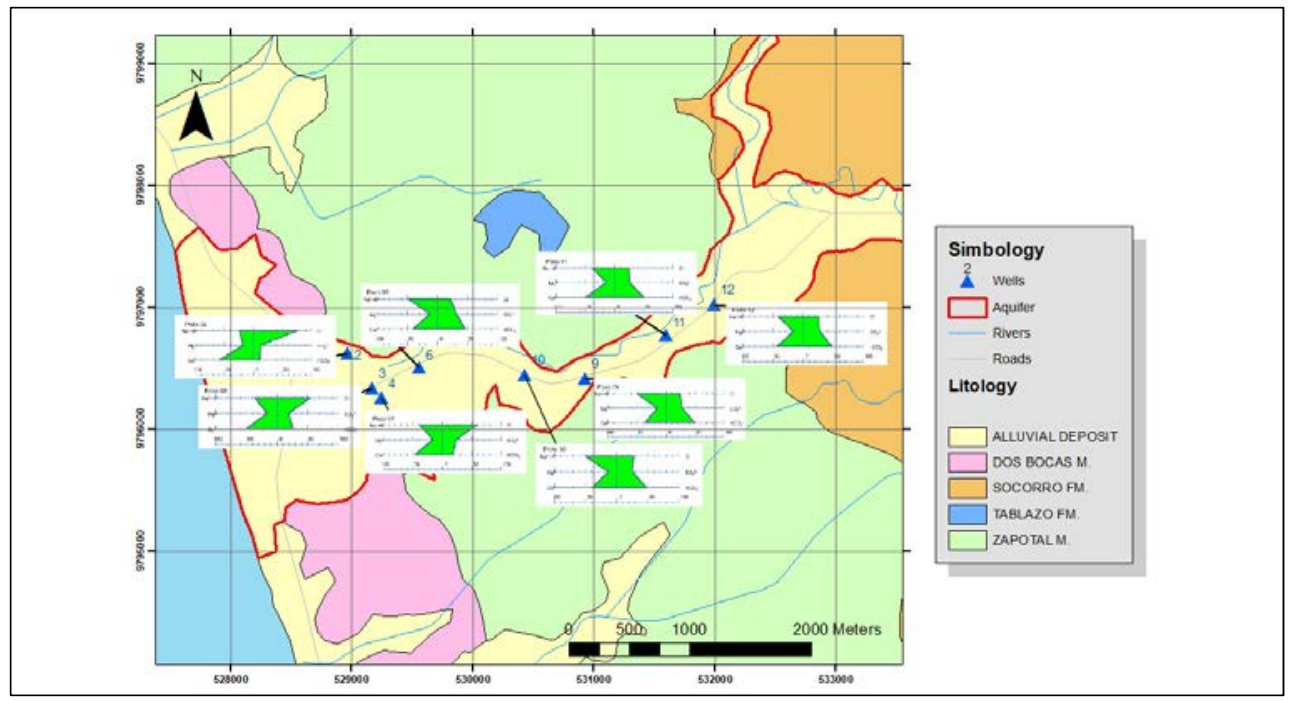

Figure 3: Stiff diagrams that spatially represent the concentrations of major ions in the Manglaralto river basin. 
The analysis carried out in the aquifer under study, according to the classification regarding the $\mathrm{Cl} / \mathrm{Br}$ ratio of Alcalá and Custodio [22], indicate that the waters that are located in the interior of the basin have a relation between 420-520, and they approximate "recharge waters," which would corroborate that precipitation is the only source of recharge for this underground system, although they are slightly concentrated in $\mathrm{Cl}$. The samples analyzed from the wells closest to the basin are within the range of the ones located further into the basin, but they differ in the concentration of chloride, since it increases, approaching according to the classification to types of waters that have been affected by human activity (Fig. 4).

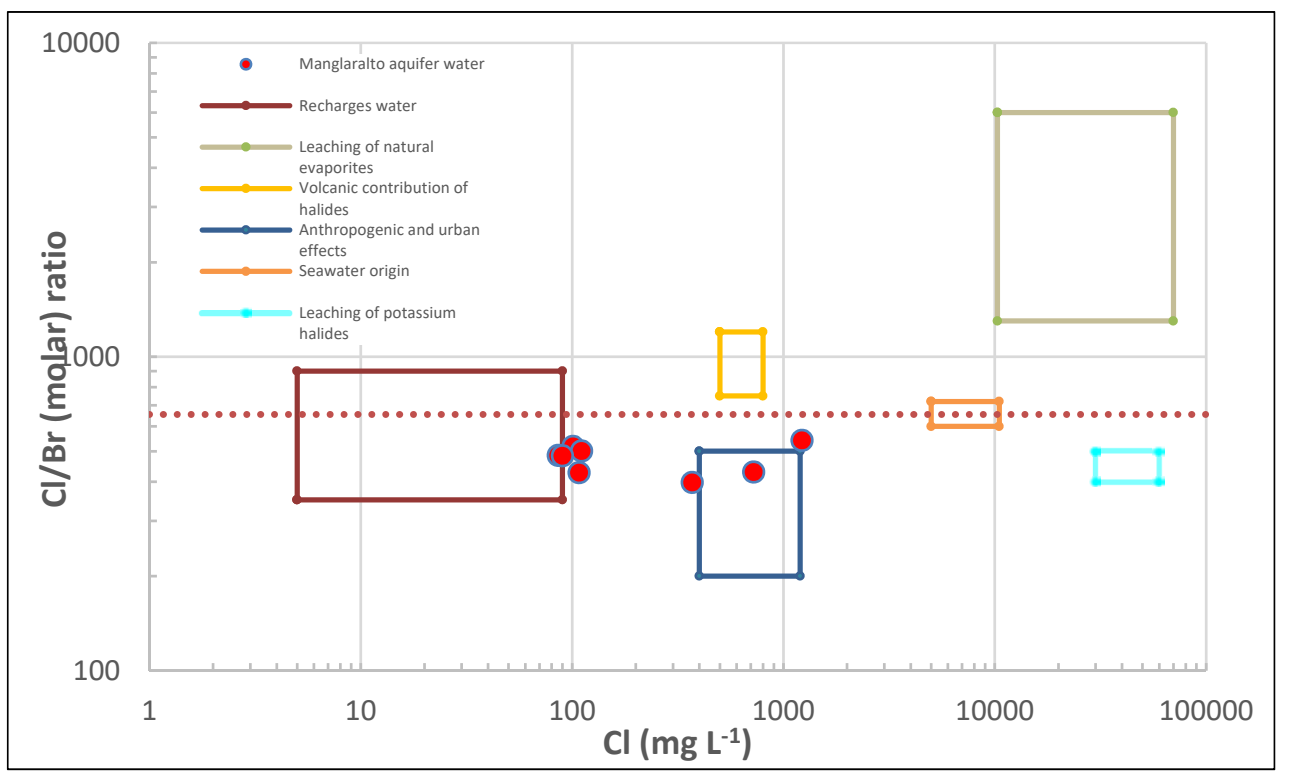

Figure 4: $\mathrm{Cl} / \mathrm{Br}$ ratio of the waters of the Manglaralto aquifer, in which, according to the classification of [22], they are recharge waters with different concentrations of $\mathrm{Cl}$ depending on where they are located spatially.

\subsection{Hydrogeological conceptual model}

The hydrogeological system of the Manglaralto aquifer consists of a groundwater flow that flows through alluvial deposits of Holocene age, with this lithology capacity of 3-5 $\mathrm{m}$ in the upper basin, while in the middle and lower basin it can reach $25-30 \mathrm{~m}$ thick. The base of this hydrogeological system is made up of the lithological sequence described in the geology of the site, which presents mainly carbonates in its composition and which contributes this trace to the groundwater product of the dissolution, in addition it is indicated that these geological formations were exposed to a marine environment, so the chlorides were contributed by transgressions and marine regressions, which is reflected in the concentrations of this ion within the basin by $\mathrm{Cl}$ dissolution processes. The recharge of the aquifer occurs directly by the infiltration of rainfall in the alluvial materials that make up an alluvial terrace along the basin and by the infiltration in the river bed when surface runoff occurs, this in the rainy season (January-May) and in the denominated "garúa", that is a very fine precipitation with 
very small drops, the one that occurs in the months with the temperature the lowest in the region (June-October). The outputs are mainly due to the extractions that JAAPMAN performs to supply the population, the ETP, which is high and directly affects the water deficit that exists and the natural discharge to the sea. An important section in the coastal aquifers is the saline intrusion, which would be reflected in the typical increase of chloride concentrations in the wells analyzed closer to the sea, which would indicate that the aquifer in this area would be affected, in terms of quality of water for water supply.

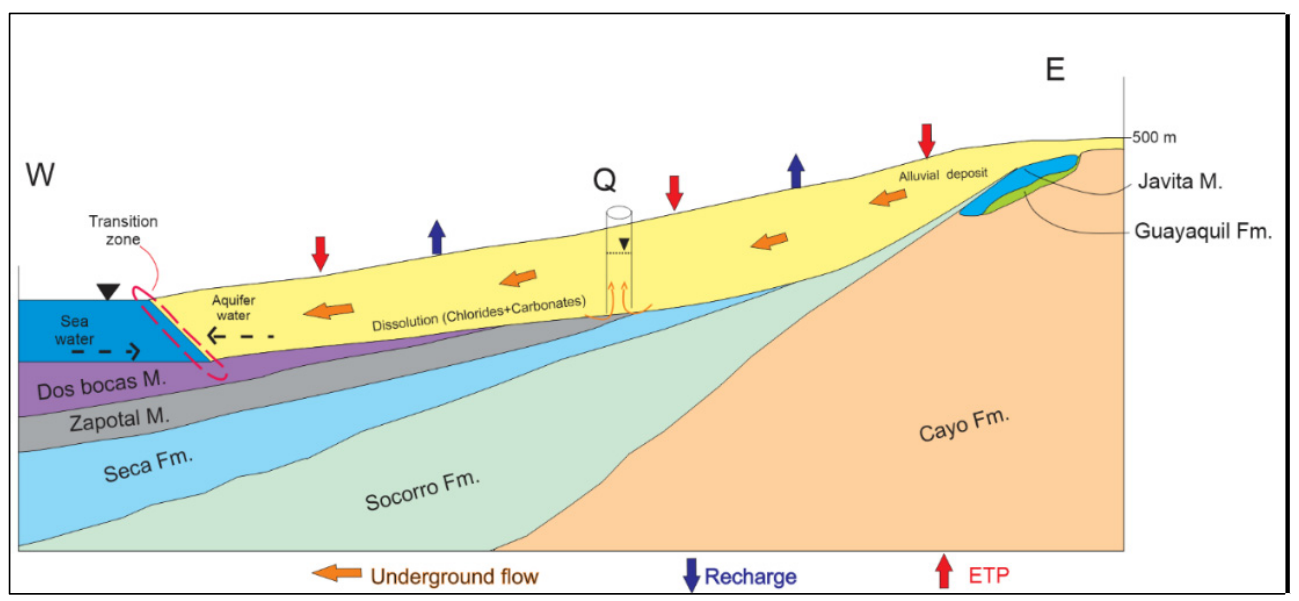

Figure 5: Conceptual model of the hydrogeological system of the Manglaralto river basin.

\section{DISCUSSION}

The alluvial terrace object of this study rests on calcareous rocks of Upper Javita of the Fm. San Eduardo, Fm. Help, Fm. Dry, Dos Bocas of the Fm. Tosagua, due to marine transgressions and regressions, which would be contributing to the bicarbonate footprint of the first family of waters present from the interior of the basin, which would be a dissolution process, as well as chloride concentrations that remain constant in This family of waters, which would lead to acquire this chemical imprint of the base of the aquifer, being very porous rocks and having been related in the past to a marine environment. The chloride was trapped in these pores and dissolution effects are concentrated in this ion, then mixed with the recharge water from precipitation, as is the case of some aquifers and also Manglaralto, in which chloride concentrations they occur mainly by dissolution of evaporite materials and mixing of the recharge water [23], [24]. The origin of the salinity is important, this is because the groundwater is used for supply, in the case of this aquifer, the EC is in the range of $1500 \mu \mathrm{S} / \mathrm{cm}$ up to $7000 \mu \mathrm{S} / \mathrm{cm}$, inside the basin and next to the sea respectively, as indicated by the US Salinity Laboratory [25], in which above $750 \mu \mathrm{S} / \mathrm{cm}$ is water of poor quality for human consumption. The origin of salinity in the aquifer, mainly in the interior, which apparently does not have a direct influence from the sea, could acquire chloride ions mainly from the base of the aquifer, since this geological formation was exposed in the past to an environment marine, and if we consider the $\mathrm{Cl} / \mathrm{Br}$ classification proposed by Alcalá and Custodio [22], both groups are in the range of influence of recharge water $(\mathrm{rCl} / \mathrm{Br}: 420-520)$. The waters within the basin correspond to recharge water, which is in accordance with the conceptual model proposed in this work. The aquifer waters closer to the sea, according to 
this classification, are framed in those that have been affected by man, since these wells are close to the urban area, in addition to the marine influence. The marine intrusion in this aquifer, could be present given that the analyses indicate high chloride contents, they are also those that have the highest concentrations of CE, which leads to think of the existence of a marine intrusion, which is why this concentration, that is, the mixing of water from the aquifer with sea water, this would be mainly due to overexploitation of the free aquifer, causing this piezometric levels to become depressed and the sea water to advance [26]; however, other coastal aquifers do not owe these concentrations only to this mixture, but other processes such as halite dissolution are involved [23], [27]. The waters of the aquifer present a very marked trace of bicarbonates, which would be obtained from the interaction of the carbonate rocks existing under the aquifer; or also, when recharge by infiltration occurs vertically, since the materials that make up the alluvial, are rocks that are present in the geological formations of the basin, so they can dissolve these carbonated materials [26], [28].

\section{CONCLUSIONS}

The hydrochemical characterization indicates the existence of two water families: the first one, bicarbonate and calcium-sodium, which correspond to those of the interior of the basin, while the second family, which are closest to the sea, contains markedly calcified calcium facies, which indicates that this family is affected by marine intrusion. The EC is in a range between $1500 \mu \mathrm{S} / \mathrm{cm}$ (inside the basin) to $7000 \mu \mathrm{S} / \mathrm{cm}$ (near the sea), which indicates that it is above what is allowed for drinking water $(750 \mu \mathrm{S} / \mathrm{cm})$, given high concentrations of chloride, due to dissolution processes in the interaction of the recharge water with the calcareous rocks of the base of the aquifer, which trapped chlorides when exposed to a marine environment in the geological past, with the geological and hydrochemical data, a conceptual hydrogeological model was reached that explains the salinity in the nearness of the coast, and the chloride concentrations in the interior of the basin, upstream of the Manglaralto river. As for the coastal edge there would be a mixture of sea water with that of the aquifer that affects the wells in this area and with it the quality of the water. Anthropic activity, according to the classification of Alcalá and Custodio [22], which affects the wells near the sea, would be by a livestock farm in the vicinity, which would be affecting the water quality of the aquifer.

\section{ACKNOWLEDGMENTS}

The authors acknowledge UPSE, due to data obtained in the framework of the project No. 91870000.0000.382444, CIPAT-ESPOL for the logistics provided for the preparation of this work, JAAPMAN for their help in field work.

\section{REFERENCES}

[1] Maurya, P., Kumari, R. \& Mukherjee, S., Hydrochemistry in integration with stable isotopes $(\delta 18 \mathrm{O}$ and $\delta \mathrm{D})$ to assess seawater intrusion in coastal aquifers of Kachchh district, Gujarat, India. Journal of Geochemical Exploration, 196, pp. 42-56, 2018.

[2] Collet, S. \& Engelbert, A., Coastal regions: People living along the coastline, integration of NUTS 2010 and latest population grid. $\mathrm{http} / / /$ ec.europa.eu/eurostat/web/products-statistics-in-focus/-/KS-SF-13-030. Accessed on: 3 Sep. 2017.

[3] Small, C. \& Nicholls, R.J., A global analysis of human settlement in coastal zones. Journal of Coastal Research, 19(3), pp. 584-599, 2003.

[4] Lathashri, U.A. \& Mahesha, A., Simulation of saltwater intrusion in a coastal aquifer in Karnataka, India. Aquatic Procedia, 4, pp. 700-705, 2015. 
[5] Slim, D., Loeza, C., Munguía, N., Peralta, J. \& Velázquez, L., Sustainability strategies for coastal aquifers: A case study of the Hermosillo Coast aquifer. Journal of Cleaner Production, 195, pp. 1170-1182, 2018.

[6] Oude Essink, G.H.P., Improving fresh groundwater supply-problems and solutions. Ocean and Coastal Management, 44(5-6), pp. 429-449, 2001.

[7] Tosi, L., Rizzetto, F., Teatini, P. \& Carbognin, L., Saltwater intrusion in the southern catchment basin of the Venice lagoon, Italy. 5th European Congress on Regional Geoscientific Cartography and Information and System Water, Barcelona, Spain, 13-16 June, pp. 60-61, 2006.

[8] Paul, B. \& Rashid, H., Climatic Hazards in Coastal Bangladesh: Non-Structural and Structural Solution, Butterworth-Heinemann: Oxford, pp. 121-152, 2016.

[9] Pool, M., Carrera, J., Alcolea, A. \& Bocanegra, E.M., A comparison of deterministic and stochastic approaches for regional scale invers modeling on the Mar del Plata aquifer. Journal of Hydrology, 531, pp. 214-229, 2015.

[10] Han, D., Post, V. \& Song, X., Groundwater salinization processes and reversibility of seawater intrusion in coastal carbonate aquifers. Journal of Hydrology, 531, pp. 10671080, 2015.

[11] Valencia, J.I., Análisis hidrogeológico de la cuenca del río Manglaralto para la caracterización de sus sistemas acuíferos. Undergraduate thesis, Escuela Superior Politécnica Del Litoral, Guayaquil, 2017.

[12] Austin, M., Masselink, G., McCall, R. \& Poate, T., Groundwater dynamics in coastal gravel barriers backed by freshwater lagoons and the potential for saline intrusion: Two cases from the UK. Journal of Marine Systems, pp. 19-32, 2013.

[13] Beyer, M., Jackson, B., Daughney, C., Morgenstern, U. \& Norton, K., Use of hydrochemistry as a standalone and complementary groundwater age tracer. Journal of Hydrology, 543, pp. 127-144, 2016.

[14] Giambastiani, B.M.S., Colombani, N., Mastrocicco, M. \& Fidelibus, M.D., Characterization of the lowland coastal aquifer of Comacchio (Ferrara, Italy): Hydrology, hydrochemistry and evolution of the system. Journal of Hydrology, 501, pp. 35-44, 2013.

[15] Gu, X., Ma, T., Wu, Y.\& Xiao, W., Hydrogeochemical characteristics of groundwater in the Karst region, southwest China. Procedia Earth and Planet Science, 17, pp. 245248, 2017.

[16] El Universo, Problemas en Manglaralto. www.eluniverso.com/opinion/2015/10/19/nota/5192870/problemas-manglaralto.

[17] Campoverde, J. \& Fajardo, I., Contribución de la geología aplicada para la mejora en el diseño de un dique en la subcuenca del rio Manglaralto, provincia de Santa Elena. Undergraduate thesis, Escuela Superior Politécnica Del Litoral, Guayaquil, 2018.

[18] Arévalo, M., Propuesta de diseño de construcción, acondicionamiento de un pozo de agua y su incidencia en la vulnerabilidad del acuífero costero en Manglaralto. Undergraduate thesis, Escuela Superior Politécnica Del Litoral, Guayaquil, 2017.

[19] Herrera, G., Estudio para un Modelo de Gestión de un Acuífero Costero, mediante Metodologías Participativas y Análisis Geoestadístico en el marco del Desarrollo Local. Manglaralto, Ecuador. Doctoral thesis, Polytechnic University of Madrid, 2015.

[20] Núñez del Arco, E., Geología del Ecuador, ESPOL: Guayaquil, 254 pp., 2003.

[21] CIPAT-ESPOL (Guayaquil, Ecuador), SENAGUA, Proyecto mapa Hidrogeológico escala 1:250.000, Informe inédito, 2014. 
[22] Alcalá, F.J. \& Custodio, E., Using the $\mathrm{Cl} / \mathrm{Br}$ ratio as a tracer to identify the origin of salinity in aquifers in Spain and Portugal. Journal of Hydrology, 359, pp. 189-207, 2008.

[23] Kumar Mohanty, A. \& Gurunadha Rao, V.V.S., Hydrogeochemical, seawater intrusion and oxygen isotope studies on a coastal region in the Puri District of Odisha, India. Catena, 172, pp. 558-571, 2019.

[24] Shakerkhatibia, M., Mosaferia, M., Pourakbarf, M., Ahmadnejadc, M., Safavid, N. \& Banitorabe, F., Comprehensive investigation of groundwater quality in the north-west of Iran: Physicochemical and heavy metal analysis. Groundwater for Sustainable Development, 8, pp. 156-168, 2019.

[25] US Salinity Laboratory, Diagnosis and Improvement of Saline and Alkali Soils, Agricultural Handbook, No. 60, United States Department of Agriculture: Riverside, CA, 160 pp., 1954.

[26] Hana, D., Post, V.E.A. \& Song, X., Groundwater salinization processes and reversibility of seawater intrusion in coastal carbonate aquifers. Journal of Hydrology, 531, pp. 1067-1080, 2015.

[27] Argamasilla, M., Barberá, J.A. \& Andreo, B., Factors controlling groundwater salinization and hydrogeochemical processes in coastal aquifers from southern Spain. Science of the Total Environment, 580, pp. 50-68, 2017.

[28] Klassen, J. \& Allen, D.M., Assessing the risk of saltwater intrusion in coastal aquifers. Journal of Hydrology, 551, pp. 730-745, 2017. 